\title{
H.R. 3084: A MORE RATIONAL COMPENSATION SYSTEM FOR MEDICAL MALPRACTICE
}

\author{
W. HeNSON MOORE* \\ AND \\ JoHN S. HOFF $\dagger$
}

INTRODUCTION

The main proposal in the current Congress with respect to medical maipractice is H.R. 3084' (the Moore-Gephardt bill), which was widely discussed when introduced in the 98th Congress as H.R. 5400.2 The bill merits support because it cuts through the Gordian knot of tort reform, motivating medical providers to offer reasonable compensation for negligently injured patients in exchange for patients' foregoing the opportunity to pursue what is often the will-o'-the-wisp of tort recovery.

II

\section{The Genius of Simplicity}

The basic idea behind H.R. 3084 is a simple one. In response to the view that the tort system now wastes money on transactional costs and windfall recoveries for the few plaintiffs who win the lottery of litigation, the proposal would rechannel that money toward fairer and faster compensation for more victims of malpractice. Eligible victims would receive fair payment for actual pecuniary losses, without the expense, trauma, and delays of litigation. Patients would exchange the right to sue for noneconomic damages for prompt, guaranteed payment of out-of-pocket economic losses. The arrangement would directly benefit both patients and providers and would give society a more efficient means of compensating victims of malpractice.

The bill is not a no-fault proposal. To the contrary, it retains the central principle of tort law that compensation should be based on faulty behavior,

Copyright $@ 1986$ by Law and Contemporary Problems

* Member, United States House of Representatives, 6th District, Louisiana; member, Subcommittee on Health of the Committee on Ways and Means (99th Congress).

+ Member of the Bar of the District of Columbia.

1. 99th Cong., Ist Sess. (1985). The bill's genesis and rationale are more fully set forth in O'Connell, Offers That Can't Be Refused: Foreclosure of Personal Injury Claims by Defendants 'Prompt Tender of Claimants' Net Economic Losses, 77 Nw. U.L. REv. 589 (1982). The 1984 bill itself is discussed in more detail in Moore \& O'Connell, Foreclosing Medical Malpractice Claims by Prompt Tender of Economic Loss, 44 LA. L. REv. 1267 (1984).

2. 98th Cong., 2d Sess. (1984). 
and it would not provide compensation for all bad outcomes occurring in the course of health care. Given that the provider should not be a guarantor of the patient's health, however, the question remains what bad events the provider should pay for. The current tort system resolves that question by requiring the provider to pay for injuries that a jury determines to be the result of negligent conduct. Resolving issues of fault, causation, and damages through the formal adversary process entails the expense, delay, and fortuity endemic to tort litigation. The challenge is to find an alternative resolution, short of requiring providers to pay for bad outcomes regardless of negligence.

The genius of the idea embodied in H.R. 3084 is that it deflects the question of defining which bad outcomes are covered. It introduces incentives for providers voluntarily to pay compensation to victims more quickly than they could recover through litigation and avoids requiring providers to pay for all adverse outcomes, but does not entail a legislative delineation of when payment must be made. Under H.R. 3084, compensation is tied to each provider's assessment of its responsibility. When a provider concludes that negligence may be found in court, it may commit itself to pay compensation, based on the injured patient's net economic loss, and thereby foreclose tort litigation. But if the provider does not do so, a patient still retains his right to have the provider's liability determined under the current tort system, subject to full tort damages, including pain and suffering and other noneconomic damages. The desire to avoid the tort lottery and its potentially very high payouts-not to mention the cost, distraction, and unpleasantness of litigation-should motivate providers to make reasonable offers to settle on the basis of fairer, more controlled, payments.

\section{III \\ The Mechanics of Improved Compensation}

Under the proposal, the payment process would work as follows: ${ }^{3} \mathrm{~A}$ health care provider would have the option within 180 days of an adverse outcome (that is, one that could give rise to a malpractice action) to make a commitment to pay the patient's net economic loss resulting from the event. The patient would be entitled to complete reimbursement of out-of-pocket losses, such as lost wages and extra medical expenses, less any payment available to the patient from other third-party sources, such as the patient's own health insurance. Counseling, pain treatment, and other costs would be reimbursable. The compensation payments would be made periodically, as the patient's economic loss accrued, so it would not be necessary for the

3. H.R. 3084 is model legislation for the states to consider. The discussion in this article is based on the basic federal model. If a state does not pass legislation making reforms similar to those of H.R. 3084 for all health care provided in the state, H.R. 3084 would become effective for all health care provided to persons who receive assistance from the federal government in financing that care. Because of the impact of Medicare, Medicaid, and federal grant programs, this provision would provide a significant element of reform, even if a state did not act. 
proposal to operate to know or estimate the amounts actually to be covered at the time the commitment is made.

Once a provider makes such a commitment, the patient's right to pursue a malpractice claim under the tort system would be terminated, with two exceptions discussed below. Thus, in exchange for the provider's prompt assumption of responsibility for economic loss, the patient would lose his or her legal claim for noneconomic loss. In the absence of such a timely commitment, the patient could either proceed with a malpractice action exactly as under current law, or, the bill provides, obtain speedy arbitration of the issue of the provider's fault (and, if successful, recover net economic loss).

Why would providers make such offers? Because they know the tort system does not work to their advantage. The opportunity to avoid the tort lottery is limited to $\mathbf{1 8 0}$ days. Because the outcome itself starts the clock, the proposal encourages providers to develop measures for identifying possible malpractice quickly. Under the tort system, providers and their insurers receive no certain reward for prompt intervention, and may be tempted to wait for the patient to make a claim, all the while hoping that the problem never comes to light. Under H.R. 3084, providers and insurers can mitigate damages only by identifying and acknowledging any malpractice quickly, informing patients, and taking remedial measures.

In some instances, prompt provider action is impossible because no one can possibly learn of a negligent injury or because only a patient knows of the problem. For instance, problem childbirth, erroneous diagnoses, and failure to provide informed consent may all take time to discover. In such events, the provider's option to make a payment commitment would be triggered by the receipt of a claim, rather than by the "event" itself.

The commitment to pay compensation for the patient's net economic loss as it occurs would be fully enforceable as a matter of law. Net economic loss is a reasonable standard of compensation, prompt payment of which would greatly benefit injured patients. It would encompass the actual, out-of-pocket cost of continued medical and hospital care, rehabilitation, nursing care, wage loss, housekeeping services, and adapting the patient's house and car, as well as reasonable attorney fees incurred in advising the patient. ${ }^{4}$ Further, no question about the reasonableness of the promise can delay the commitment, since the qualifying tender is not a fixed estimate of future damages, but a commitment to pay specified elements of loss in full as they come due.

When one potential defendant makes a commitment under the proposal, the patient should not retain the right to sue other participants in the same alleged malpractice. Otherwise, the plaintiff would get the best of both worlds-prompt payment of out-of-pocket loss without litigation, plus the ability to sue any or all of the other participants in the alleged wrongdoing for duplicate damages. If anything, payment from one defendant would enhance the plaintiff's capacity to hold out against the others. The tort system, with all

4. H.R. 3084 places no limit on the wage loss for which the patient would be reimbursed. 
its faults, would remain essentially unchanged. Insurance premiums could only continue their rise.

To avoid this result, the bill permits a provider to join other potential defendants in the commitment to pay the patient's net economic loss. By doing so, the first provider bars a suit against the others. Similarly, the bill gives the other potential defendants the right to be included in the commitment. Thus, if a hospital commits to pay a patient, it may designate a physician as a cotenderer. A physician tenderer, likewise, may designate the hospital. Either may also designate, for example, a drug or equipment manufacturer.

The joint participants could decide among themselves how they will share the obligation owed to the patient. Since these parties are likely to be represented by insurance companies that deal with one another on an ongoing basis, they will in most cases easily agree on their respective shares, according to private rules of thumb and practiced negotiation. If they cannot agree, such disputes would go to arbitration to determine the parties' respective shares on the basis of relative negligence. This procedure not only can be conducted more expeditiously than under the current litigation system, but it also can be conducted routinely and privately, among knowledgeable professionals, rather than in the glare of publicity that can accompany litigation.

Joining the potential defendants in the commitment makes it unnecessary for the patient to determine which defendants may be culpable. The victim is also protected from the evasive mutual finger-pointing that is so common (and expensive) among various tort defendants. On the other hand, the victim cannot play one defendant off against another. In sum, the proposal is elegantly simple: the patient receives just compensation, the participants are obligated to pay it, and the liability insurers determine the respective shares. ${ }^{5}$

How many adverse outcomes could be expected to come under the proposal? More than under the current tort litigation system, but less than under proposed no-fault schemes. First, providers and their insurers would be certain to make offers in all cases of clear liability when there is a reasonable probability of lawsuit or claim; committing to pay net out-ofpocket costs is a much better "deal" than paying full damages (including amounts duplicated by collateral sources), plus pain and suffering, plus the very high "carrying charges" of the tort litigation system. Moreover, concerned providers can avoid the enormous personal agony, lost time, and professional damage of potentially protracted litigation. Second, tenders should also include cases where liability is less clear. Providers distrust the litigation process; the prospect of avoiding it will be attractive. Further, even though concepts of fault will still remain as the determinant of ultimate liability, providers will be able to present their offer in a nonadversative,

5. Not all commentators agree that this proposal would work so smoothly and inexpensively. See, e.g. Danzon, The Medical Malpractice System: Facts and Reforms, in The EfFects of LiTIGATION ON Health Care Costs 28, 34-35 (M. Baily \& W. Cikins eds. 1985). 
healing spirit: "We're not sure exactly what happened or who, if anyone, may have slipped up, Mrs. Jones, but you clearly have been disadvantaged. So all of us involved agree to take care of your extra long hospital stay and lost wages. We trust this will help you recover more rapidly and ease any fears you may have about meeting your bills in the meantime." Health care providers often want to take this approach, but the current litigation system bars them from doing so. The proposal would permit providers to be true to their caring mission, to their own benefit and that of the patient.

It is important to reemphasize that this is not a no-fault proposal. Providers are not required to make tenders for any maloccurrence in the course of health care or even for any defined list of them. The proposal is not intended, as some commentators have erroneously asserted, to have providers "routinely ma[k]e settlement offers on a no-fault basis." 6 Rather, the proposal contemplates that they will make offers when they recognize they are at fault or when there is a colorable claim of fault that the providers believe is sufficiently likely to be accepted by the jury to warrant, in light of the potential recovery, making a tender. Providers and their insurance companies will make those determinations in the context of a fault-based system for determining liability and compensation.

A proposal that required providers to make payment for all medical mishaps or that intended such a result would be inappropriate. It is far less clear in medicine than in other activities that injury has resulted from lack of care (poor medical treatment) rather than merely from the normal course of events (the natural history of the preexisting injury or disease). Under most circumstances, for example, one expects to navigate the streets safely; if that expectation is not fulfilled, it is almost invariably the result of an extrinsic act which should be compensated. No-fault automobile insurance is appropriate because the insured event (an accident) and subsequent damages are almost always a direct result of the insured activity (driving or car ownership). Disease and death, on the other hand, are inevitable-and naturally associated with medical care. To introduce a no-fault scheme for health care would require paying compensation for a large number of events that are not now actionable and are unavoidable in any case. ${ }^{7}$

It would also be extremely expensive to require compensation for all bad events arising out of health care-or even many of them. Any such scheme would effectively create a very broad health, safety, and life insurance program-a major social undertaking that would raise numerous problems of its own. The benefits of such a program would be fortuitous. Those who became ill or died while under medical care could recover, while those who died before entering the health care system could not. Sick and injured people would hasten to involve health care professionals, a practice which might benefit patients but would also be extremely expensive and require a

6. Id. at 34-35. (1978)

7. See, e.g., Mills, Medical Insurance Feasibility Study: A Technical Summary, 128 W.J. MED. 360 
massive reallocation of resources. ${ }^{8}$ Such a broad no-fault approach would not and should not be popular in Congress, especially under the present fiscal circumstances.

\section{IV}

\section{The Maintenance of Deterrence}

Some commentators have objected that H.R. 3084 would reduce the deterrence against improper conduct that the tort system now supposedly provides. ${ }^{9}$ This fear is misguided for several reasons. First, today's insured malpractice system provides precious little deterrence as it is. The great majority of malpractice payments are not made by the tortfeasor, but by liability insurers that seldom adjust rates individually in response to an insured's conduct. Second, any deterrence that exists currently would remain under the proposal. Only by guaranteeing payment of an injured patient's net economic loss-not an insignificant commitment-can a provider foreclose a malpractice claim (and even then not in every case). Fault-based tort rules would continue to set the basic framework of responsibility. Third, professional pride, the mission to serve patients and earn the esteem of one's peers, and the threat of peer review or disciplinary proceedings are all effective deterrents to malpractice-none of which the proposal would in any way reduce. If anything, professional self-review would be enhanced by the incentive to uncover potentially actionable occurrences within 180 days.

Finally, by enacting workers' compensation and automobile no-fault laws, society has already abandoned liability rules based on fault for whole sectors of modern life, apparently without any adverse effects on people's desire to avoid negligence. There is no reason to believe that health care would prove different. In fact, there are more nontort protections that ensure the quality of health care than there are in other areas in which the fault concept has been abandoned. Thus, there is little cause for concern about maintaining whatever deterrence now comes from the antiquated tort-plus-malpracticeinsurance system.

\section{$\mathrm{V}$ \\ Special Rules for Unusual Cases?}

Under H.R. 3084, a provider commitment would not terminate a malpractice claim when a patient died from the treatment or when the provider's malpractice was intentional; the most serious cases would thus be dealt with through use of the current system. Many advocates of the proposal, however, believe that there should not be an exception for death.

8. See Danzon, supra note 5 , at 35.

9. Alternative Medical Liability Act: Hearings on H.R. 5400 Before the Subcomm. on Health of the House Comm. on Ways and Means, 98th Cong., 2d Sess. 100, 102 (1984)(statement of Patricia Nemore, staff attorney, National Senior Citizens Center); id. at 103, 106 (statement of Judith Waxman, staff attorney, National Health Law Program); id. at 169, 171 (statement of Melvin Nevitt, American Association of Retired Persons). 
In other instances, a serious injury may result from malpractice but may entail little or no economic injury (particularly if there is compensation from other sources). For instance, a lawyer who loses an arm can still practice law and is probably well-covered for temporary loss of earnings and extra medical bills. Arguably, providers should not pay less for such injuries, as they do under the proposal, because the noneconomic damages (such as loss of quality of life) remain high and because economic damage was only fortuitously avoided. Nonetheless, H.R. 3084 declines to make an exception for these unusual circumstances. A commitment to pay economic loss forecloses a suit for noneconomic damages, even in these cases. Objective need for reimbursement of out-of-pocket expenses is the most important element of compensation. To make an exception and permit a patient to recover in some cases (if the cases could be defined) inevitably would open up the proposal to undue expansion through an ever-growing loophole for seemingly sympathetic circumstances.

The question presented is whether society should provide compensation for noneconomic losses. Few victims of misfortune receive payment even of their pecuniary losses-which is exactly what the bill would motivate providers to guarantee as a condition of foreclosing a tort action. The bill represents a balance. Compared with today's system, it would provide more compensation for pecuniary loss, more promptly paid, for more victims of malpractice, with far lower transaction costs and hence lower insurance charges per case.

To achieve all this on a voluntary basis, however (since providers are not obligated to commit), savings must be wrung out of the present system by reducing the amount of litigation and the amount paid on various theories of noneconomic injury. Making an exception to permit individuals to bring suit and to collect noneconomic damages in addition to their economic loss would reduce, and perhaps eliminate, the savings available to pay more victims for their economic loss, and would certainly remove providers' incentive to commit and thereby stay out of court. Nevertheless, if the societal decision is that noneconomic losses should be compensated in some cases, the proposal could be modified to do so.

One approach would be to allow suit when it would be deemed unconscionable to bar the patient from noneconomic damages. "Unconscionability" could be judged by the standard that judges use to set aside, on the basis of fraud, settlements of liability claims that were voluntarily made. If a court found that the payment of benefits under the proposal plus the amounts payable by collateral sources was so inadequate that it would have set aside a settlement on those terms, the court would allow a subsequent tort claim for noneconomic damages despite the existing commitment to pay economic loss.

Another approach would give the patient an option in all cases to accept or reject a commitment to pay pecuniary losses. A patient who rejected the offer would not be permitted to sue for compensation of economic loss, which he 
or she had just turned down, but could seek payment only for other, noneconomic damages. This option could also include a ceiling on allowable noneconomic damages. Such a cap would be more likely to withstand constitutional challenge since it would be part of a comprehensive reform scheme which offers substantial benefits to patients as a class, in contrast to an across-the-board limitation on tort recovery, which gives no benefits to the patient, forcing him to undertake litigation while also limiting the amount of recoverable damages.

Some commentators have also argued that an injured patient should be able to require that a provider promise payments. ${ }^{10}$ Although it is superficially plausible to reason that the decision to cover actual pecuniary damages should not be solely one-sided, the idea could not work in practice. Like the broad no-fault approach already discussed, a patient-initiated provider commitment would degenerate into a national health and safety insurance program, all financed through doctor and hospital bills.

To answer this point, H.R. 3084 contains a mechanism not included in the prior bill. It gives patients some additional power, when a provider does not make a tender, by allowing them to seek binding and expeditious arbitration of whether the provider was responsible. If the patient demonstrates the provider's fault, he or she could collect net economic loss, as if a tender had been made, but would not receive any noneconomic recovery. To try for the "big score" of full tort damages, a dissatisfied patient would have to eschew arbitration and submit to the full panoply and all the delays of the tort litigation system itself.

\section{VI \\ ConcLUSION}

There is little doubt that the present system for compensating victims of malpractice fails to serve its intended purposes. It is unfair to patients and providers alike, and burdensome to society as a whole. Litigation is not a humane or efficient way to compensate victims of malpractice. The federal government has a leadership role to play in encouraging reform. Because it funds a large portion of the nation's expenditures for health care, it also has a direct financial interest. As a proposed federal response to the malpractice insurance crisis, H.R. 3084 provides a model for the states to consider which would become law with respect to beneficiaries of federal programs if states do not respond. It offers a better alternative. Without abandoning the salutary principle that compensation for medical injuries should be based on fault, the bill would encourage providers to compensate patients who are injured by malpractice and to compensate them quickly and without litigation.

10. E.g., id: at 101 (statement of Patricia Nemore). 